\title{
Power Populism
}

\section{The Battle between Putin, Trump, and the Liberal Elite}

\section{Matthew Crosston}

\author{
Matthew Crosston \\ Institute of National Security Studies, Tel Aviv, Israel \\ Senior Research Fellow \\ Scopus ID: 25221210000 \\ E-mail:matthew.crosston@gmail.com \\ Adress: 140 Wexford Dr., \#205, Anderson SC 29621 \\ DOI: $10.31278 / 1810-6374-2020-18-1-38-58$
}

\begin{abstract}
In traditional understandings of classical populism, power is commonly defined as being in need of devolving from the corridors of power and out to a more grassroots foundation. At its core, populism was usually seen as a belief in empowering regular people. 'Regular people' were typically defined as being disconnected, if not outright disenfranchised, from central power and outside the realm of the 'elite.' This paper investigates the modern phenomenon in Russia and America that turns these traditional concepts completely on their head. Rather than being a movement engineered against elite political insiders, populism in America and Russia currently seems to be occupied by the elites of society. Ironically, these elites position themselves as the chosen representatives of the disenfranchised. These strange bedfellows have arguably produced a new form of 'power populism': instead of being focused on removing power from the state, this populism is founded more upon strengthening the global position of the state while tacitly dismissing/attacking the perceived intellectual elite of each society. Dissecting this phenomenon and concluding what trends may emerge
\end{abstract}


from it will go a long way in predicting possible future changes in Russian-American relations. ${ }^{1}$

Keywords: populism, Russia, elites, Putin, Trump, social elites, power populism, the Battle between Putin, Trump and the liberal elite

$\mathrm{n}$ traditional understandings of classical populism, power is
commonly defined as being in need of devolving from the
corridors of power and out to a more grassroots foundation. At its core, populism was usually seen as a belief in empowering regular people. 'Regular people' were typically defined as being disconnected, if not outright disenfranchised, from central power and outside the realm of the 'elite' (Acemoglu, Yegorov and Sonin, 2013, pp. 771-774). This paper investigates the modern phenomenon in Russia and America that turns these traditional concepts completely on their head. Rather than being a movement engineered against elite political insiders, populism in America and Russia currently seems to be occupied by very specific segments of elites in society. Ironically, these elites position themselves as the chosen representatives of the disenfranchised.

These strange bedfellows have arguably produced a new form of power populism: instead of being focused on removing power from the state, this populism is founded more upon strengthening the global position of the state while tacitly dismissing/attacking the perceived liberal intellectual elite of each society, where the true

\footnotetext{
$1 \quad$ Please note that this article diverges from the standard scholarly process in that there is a concerted effort to not single out or highlight a single scholar's analysis in which to emphasize a specific flaw or inherent hindrance currently affecting Russia analysis when done in the West. This is what causes the relatively small amount of footnotes. The reason for this is because the flaws mentioned herein are truly emblematic of the discipline as a whole. As such, giving any reader the impression that specific scholars are being purposely identified is the last thing this article wishes to do. Rather, it is the bias, and from whence it came, impacting the entire discipline of Contemporary Russian Politics in the West that is of paramount focus. To be sure, the arguments made here are not facetious or without evidence, thus, specific notes are given intermittently. Again, those notes are not meant to implicate individuals but ground the larger argument. Simple Google searches of the criticisms offered will reveal a massive trove of evidence, written by literal dozens. Therefore, once more, the importance of this article is not in throwing stones at people, but prodding discussion and debate at an entire research area.
} 
proponents of traditional populism tend to reside (Oliver, Rahn and Bartels, 2016, pp. 193-197). Dissecting this phenomenon (including an examination of how the phenomenon of 'post-truth' politics plays an important role in the geopolitical prediction of where this disturbing new form of populism may go) and concluding what trends may emerge from it will go a long way in predicting not just future trends in domestic politics but the very future of RussianAmerican relations on the global stage. Because if one thing seems to be clear, there is a distinction between traditional populism and this new power populism, namely their ultimate positions of focus: no longer enthralled with traditional populism's concentration on improving and making a more just society and access to domestic governance, power populism is perhaps more obsessed with ensuring the success, strength, and prestige of the state on the international stage (Ding and Hlavac, 2017, pp. 441-444).

In some ways, it can even be argued that these leaders have somewhat coopted the classic Marxist critique of populism (that is basically a diversionary tactic of the bourgeoisie to deflect class anger away from real socialism and to focus instead on empty promises of false reform). The difference, of course, is in the end goal: rather than using the critique to push people towards a more genuine form of socialism, both leaders simply reinforce the dismissal of the liberal elite as justification for the people to believe more strongly and more faithfully in their segments of the elite. Since populism has always, in the end, tended to be very conservative in cultural terms, both Putin and Trump are therefore tapping into populist traditions that are quite ancient, even if many American media outlets portray their efforts to be quite the opposite. Thus, even if Trump and Putin are criticized for their supposedly innate desires to return to a 1950s white male world and a vigorous Soviet world of global respect/fear, respectively, as being wholly anti-populist by liberal elites in each society, the utilization of populism by leaders throughout time and space (William Jennings Bryan, Rodrigo Duterte, Ferdinand Marcos, and Anastasio Somoza just to name an extremely diverse few) has always been socially constructed and aimed for producing quite different political content. 


\section{A BRIEF IDEATION OF POPULISM}

From its very beginning in the 19th century, populism as a political concept has often been commandeered, steered, managed, and diverted by various groups, politicians, organizations, and countries. So much so that there has always been intermittent calls from academia to do away with the term altogether, given its apparent wild and inconsistent fungibility (Nicholson, 2011, pp. 1167-1169). Despite these valid criticisms, it is still fair to point out a traditional take on populism that has fairly dominated the political scene for well over a century. This more dominant take stipulates that populism as an ideational force is always meant to represent 'the people' as a morally good foundation for society at large and contrasts this against an 'elite' that distinctly wears the black hats in society, largely being self-serving and corrupt. The ultimate goal of populism, therefore, is creating whenever and wherever possible a political momentum and societal shift where 'power' ends up no longer concentrated in the hands of disconnected elites and rests instead in the more deserving hands of 'the people' (Plattner, 2010, pp. 81-85).

The problems, as most can readily see, is the lack of any precise definition of terms when it comes to such critical concepts as 'people', 'elites,' and 'power.' Since there has never been explicit consensus over how those three terms are defined, this is what leads to the aforementioned inconsistency. It is not so much that populism is not admired or embraced as a concept. Rather, it is how much any and every group tries to position itself as 'the people,' thus rationalizing and justifying anything within their given agenda as noble and righteous. Despite this definitional problem, the reality is populism as a political movement has traditionally always been about standing up for the powerless and standing firm against the powerful who must inevitably always have interests that contradict the former (Mead, 2017, pp. 2-5). More than anything, it is about producing a more just, fair, equitable, and prosperous society for all, not just the top one percent.

It is understandable how populism has always come to be associated with democracy as the spirit underpinning a political system. The aligned principles of equal representation, open participation, transparency, and the rule of law all highlight and form a political 
momentum for the overall goals of traditional populism (Berlanga, 2010, pp. 156-158). As mentioned above, its ultimate fight is against the privileged and connected and how often they engineer the system to benefit only themselves while continuing to exploit the vast majority. Where it gets a little messy (and where it will be seen later in this article as a crucial element of populism's future manipulation), is how populism-even this most traditional mass-oriented form-has always produced individual charismatic figures to lead 'the people' (Rose, 2016, p. 1). Rather than being egotistical and narcissistic, as populist political cartoons tend to characterize the charismatic leaders of the elite, many populist leaders have tried to characterize themselves as selfless voices, conduits to transmit the true desires and interests of the people themselves. This is also why populism in America over the decades has traditionally found its ideological home on the decidedly left side of political spectrum (Plattner, 2010, pp. 86-88). What is interesting in the cases of Trump and Putin is their unity on not positioning themselves as 'common men,' as it were, but still the leaders more fluent in understanding the needs of common people. Their unique talent in achieving this with a significant segment of their societies is yet another way in which traditional liberal elites underestimate their abilities to let populism work for them and their political agendas.

More recently, populism has split into right-wing and left-wing camps, while simultaneously striving to maintain their bona fides as being the "true" representatives of the interests of 'the people.' In this dynamic, one that we see playing out most prominently across mature democracies in the West, most particularly Europe and United States, right-wing populism still maintains the standard tête-à-tête of the people fighting the elite. The innovation (not positive) is in reframing the elite: instead of being the rich and powerful corrupt kleptocracy, the elites in this version are seen as the idolized liberal intellectuals and their incessant noble causes that de facto isolate and ignore the justified concerns and indignation of the 'true masses' (Winberg, 2017, p. 86) This characterization is passionately endorsed by many on the right, while being decried by the left as a deformation of 'real populism, i.e., trying to hide the fundamental essence of racism, 
sexism, chauvinism, and nationalism running amok within the rightwing version (Huber and Schimpf, 2017, pp. 151-155). The following analysis of contemporary populism debates within Russia and America will provide a vivid backdrop to this ideational evolution and reveal just how important the real-world political consequences are, especially when considering future Russian-American relations.

\section{A TARGETED HISTORY OF 20TH CENTURY RUSSIAN POPULISM}

The discussion first needs to consider the Soviet legacy before considering contemporary Russian political expressions of populism. While both critics and Russophiles will wax poetic about the still-existing legacies and endowments that stretch all the way back to Russian medieval times to today, the more pertinent and explicitly direct path is located in the original Russian revolution (the Lenin one) to now. The single biggest negative innovation of Lenin (at least if you asked Marx, who saw this as a betrayal of his more organic foundations of the socialist revolution) was the concept of creating a 'vanguard of the people' (Smith, 1955, pp. 550552). There are many ways to explain the relevance of the concept, but for this current discussion the focus is on how this was the first explicit construct within modern Russian society where leadership expressed the idea that populism, if it was going to take its ideal form and achieve its maximum impact, needed to be guided and managed from above. Marx, of course, hated and spurned this idea, given his entire original treatise was based on the principle of the working classes rising up and throwing off the yoke placed upon them by the exploitative elite without the help of any upper-level elite management.

But this control was deemed crucially necessary by Lenin and his colleagues, given the almost universally accepted idea at the time that Russian society, the so-called masses, was utterly incapable of organizing and achieving such a noble goal as a truly communist society. While there is no desire nor need to give a literal laundry list of subsequent Communist leaders after Lenin that would either continue this basic premise or distort it even more grotesquely in favor of elite control, the fact remained steady: Russia/the Soviet Union educated its people throughout the entire 20th century on the basic principle that 
the grassroots always somehow magically gained strength when it was grown from the heights of government penthouses (Bader, 2009, pp. 110-117). Even Yeltsin, the first president of the Russian Federation after the dissolution of the Soviet Union in 1991, very quickly adapted to the style and pomp of controlling from above.

Indeed, when looking briefly over the evolution of Russian presidential power from Yeltsin to Putin, one can even see a subtle nuance developing in the concept of power populism: one that does not question its relevance but actually deepens and possibly strengthens its legitimacy from above. When Putin was 'managed' to successfully defend his interim presidency after the sudden resignation of Yeltsin on December 31, 1999, a legitimately endangered Russian Federation was at his doorstep. Out of the many criticisms thrown at Yeltsin by the end of his presidential tenure, a chief one for Russian statists was the fact that the Russian state was basically being run de facto by the interests of a self-absorbed oligarchy (Shinar, 2015, pp. 587-589). Not to defend Yeltsin, but the 1990s were a decade of overall state and demographic Russian degradation: weakening global power, domestic instability, outright insurrection/insurgency, and scarily stark health statistics made some experts in the West brazenly question the actual long-term survival of Russia as a state (DaVanzo and Grammich, 2001). Yeltsin's alignment, therefore, with powerful oligarchs can be at least partially understood if not necessarily approved.

This weakened and wounded Russia was the one Putin inherited. Thus, ironically, the shift that Putin engineered-and so often derided by Western experts today-from self-interested oligarchs to obedient and aligned security elite-was largely seen by everyday Russians as not only necessary but as a huge step in the right direction for all Russians, not just Russia as an abstract state construct (Casula, 2013, pp. 12-14). Thus, the populist nuance was that "Russian democratic populism" actually expressed itself in two completely different and antagonistic ways during the 1990s-2000s before it even came close to touching actual Western-style populism. Whether it was controlled by oligarchs or the KGB-successor FSB, both "movements" actively proclaimed their prime motivation to be serving the people and safeguarding the state. 
Both initially and substantially commanded sincere and overwhelming popular support (Lassila, 2016, pp. 123-126). Thus, when considering the modern foundation of populism in Russia, from the initial Lenin innovation to the shifting of power by Putin, one principle remains constant and undefeated: leaders will define and control what populism is, how it gets expressed, and in which direction it will proceed.

\section{PUTIN THE “MODERN RUSSIAN POPULIST"}

"In contrast to the populist image Russian President Vladimir Putin has created to galvanize support, he is part of today's Russian establishment elite. This puts him in an awkward position as populism spreads across Europe and Russia marks the one hundredth anniversary of the 1917 revolution. Should Putin again take the populist approach, he is likely to inspire accusations of hypocrisy from the opposition-minded. But without some effort to engage the Russian electorate, Putin may not achieve the strong showing in the 2018 presidential election that he needs to secure his legitimacy and cement his legacy. Putin hopes that Russians do not see the parallels between today and one hundred years ago, when Russian workers and peasants supported a change in government and called for an end to the poverty and mistreatment they suffered at the hands of wealthy aristocrats and the bourgeoisie" (Gurganus, 2017).

Despite the deep respect and global impact the Carnegie Endowment has justly earned over the decades of its existence, pieces like the one above have a tendency to be more founded on American diplomatic wishful thinking rather than an erudite analysis of empirical reality. Since most Russian experts in the West see Russia's hyperpresidential system as nothing but a cover for a de facto authoritarian dictatorship (or at least a quasi-attempted one), they tend to be blinded to any populist maneuvers by Putin, presuming the majority of the Russian people will as easily see through the gambit as they themselves do (Young, 2018, pp. 28-30). The problem with this, however, is that the mindset of Western Russia experts does not approximate the mindset of ordinary Russian citizens. It is not that Russians are dupes unable to see attempts to pull the wool over their eyes (a condescending trait that is also thinly veiled in many discussions about Russian society in the 
West) (Treisman, 2011, pp. 600-607). Rather, it is a difficult calculus: between security/stability versus rampant mercantilism void of any egalitarian characteristics whatsoever. When Western observers allow that calculus into their thinking, then the potential popular legitimacy of Putin becomes far more apparent.

The reality of the aforementioned degraded state of Russia as a country and people was mentioned earlier, perceived by many within Russia as the direct consequence of a weak Yeltsin who cozied up too close to Western economists and allowed an oligarchic system of the few to take over the country as their personal playground (Handelman, 1999). Given the psychological/scholarly trauma and legacy left on the minds of Western analysts, it is not shocking that Putin's emergence in the 2000s with his hyper-security, hyper-stability focus was immediately derided as old-school Soviet revanchism (Freebury, 2011, p. 979). But to the ordinary Russian citizen, it was quite the opposite: Putin appeared as a sober leader (literally and figuratively, not coincidentally) and his ideas on creating a more "state-managed democracy" fell decidedly in line with what the majority of the populace was craving at the time. Their perception? "Western-advised democracy running amok," as it did throughout most of the 1990s, had basically devastated the vast majority of ordinary Russians. The classic question asked back then on the street (and shamelessly given little credence at the time by Western experts) was definitive: "What is worse? Money in your pocket but nothing on the shelves or nothing in your pocket and everything on the shelves?"

For whatever reason, most in the West thought the only answer to that question was the former. But for most Russians it was decidedly the latter. To be surrounded by wealth and merchandise, supposedly the emblems of democratic freedom, but to be unable to afford any of the basic necessities was not just hardship. It was humiliation in the minds of ordinary Russians. And lest anyone forget, in the middle of this reflection, there were ample signs in every single town, in every village even, across all of Russia, where it was obvious some people were becoming rich and powerful beyond measure. But that number was extremely small and the path to become one seemed fairly narrow, 
if open at all. To ordinary Russians, this was the Russia that Putin walked into the Kremlin with. This was the Russia that needed to be fixed by a strong leader that would not ignore the people.

The ultimate divergence in understanding Putin's maneuvers in the 2000s and beyond, between America and Russia, was the inability of Western experts to see just how appealing those maneuvers would be and how legitimately they would be received as genuine populism. Putin did not so much build a cult of personality to himself based on his own greatness, on making himself seem superior to all Russians. Quite the contrary, the glorification of Putin occurred exactly because his team was able to convincingly show ordinary Russians who were struggling for survival that he understood their problems and considered those concerns legitimate and critical to the future of the Russian state (Aron, 2017, p. 78). Western experts, of course, scoffed at this idea, guffawed at the naiveté and gullibility of Russians. They kept seeing Putin as nothing but the creation of the security elite seeking to guarantee their own wealth, power, and access over Russia for the longterm. But that was their error. Even with situations apparently backing up the perception of Putin's siloviki taking over where Yeltsin oligarchs used to reign, Putin's initiatives throughout the 2000s did attempt to remedy important populist issues that had long been neglected (pensions, education, health care, employment). The West's failure to take these efforts seriously arguably allowed Putin to concretize his unique version of globalized populism, with so-called Western experts as the liberal elites needing to be vanquished. It gave Putin the international foil he so desperately wanted: a 'villain' from without to point to and proclaim as the true enemy (Staff, 2002, A1).

This phenomenon was seen most recently at the G20 Summit in 2019, when Putin confidently strode to the podium and declared that "the so-called liberal idea has outlived its purpose in the West."

"What is happening in the West?" he said. "What is the reason for the Trump phenomenon, as you said, in the U.S.? What is happening in Europe as well? The ruling elites have broken away from the people. The obvious problem is the gap between the interests of the elites and the overwhelming majority of the people" (Hodge, 2019). 
At the time, the universal Western response was derision combined with so-called benevolent warning, as many felt Putin should remember that Russia itself was extremely diverse in terms of ethnicity and religion and it might not behoove him to simply mimic the politics of Donald Trump. Once again, Western wishful thinking reared its analytically incorrect head. Putin was not mimicking the politics of Trump so much as continuing the political direction he himself started in Russia back in 2000. Russia has always been predominantly ethnically Russian and it, as a country, has never deviated from the path that while all ethnic groups within Russia are welcome, they nonetheless will have to honor and respect the fact that the Russian Federation is first and foremost Russian-prime (Leonov, 2013). This, to Russians, is not so much disrespect for other groups as much as an affirmation of their own ethnic foundation. After the beating and degradation taken for nearly a generation, one will be hard-pressed to find any ordinary Russians that find fault with the premise.

What matters even more in the above quote is the deft shift in carving out a variation within the definition of 'elite.' Putin's recent speech at the G20 was founded on a point he has made for nearly twenty years now: that the American model of democracy is by no means the only one nor is it necessarily the ideal form of democratic expression (Staff, 2011a). The fact that most members of Western academia have always simply dismissed this as authoritarian pontification speaks poorly of Western analytical nuance: sometimes what matters most is not what is factually true but what is emotionally believed in and perceived by a significant portion of the population. In global affairs and national security, to be sure, understanding the difference between these and its importance for real world affairs is absolutely critical (Mersol, 2017, pp. 97-99). Putin has always known this within the arena of Russian politics. This combination-biased Western analysis and deft Russian politicking - is why America has produced too many examples of semi-accurate analysis when it comes to the Russian Federation.

As will be seen later in the Trump section, this ability of the powerful to reverse the spotlight and aim it elsewhere is a critical, undervalued talent in right-wing populism. Unlike traditional 
conceptualizations of historical populism, where power concentrated in the center was universally deemed dangerous, the teams behind both Putin and Trump succeed in bringing layers to how a society would define 'the elite' and then shift the blame. Consequently, the true danger to 'regular folk' was not so much the rich and powerful, but the liberal elite with their intellectual snobbery and disdain for simple people. While arguably Trump's team has elevated this ability to heights never seen before, Putin's team has successfully globalized the phenomenon, making the snobbish intellectual elite not restricted to inside the borders of the Russian Federation.

\section{THE TRUMP BRAND OF POPULISM}

Most of the initial new populist bloom has by now at least faded somewhat from the Trump rose. This does not mean he is fated to not win re-election in 2020. The Democrats have still not done a good job in the years since his victory in 2016 to convince the necessary groups that they understand their concerns and give them credence. But as of today, Trump has proven himself legislatively as a more tried-and-true old-school Republican, what once would have been called a Reagan Democrat, than any kind of revolutionary new right populist. But it was this latter possibility, that he might be the new leader of a new kind of populism, is what powered what hope there was behind his shocking surprise in the fall of 2016.

Sometimes it can seem as if the liberal intelligentsia in America has difficulty getting out of its own analytically condescending way. Just as what happened with George Wallace in 1968, when the Southern firebrand was deemed, as a presidential candidate, just a redneck racist with no appeal beyond the Deep South, liberal analysts have dangerously ignored a similar geographic and cultural spread of resentment that the Trump candidacy has so effectively tapped into (Staff, 2016, p. 42). There were significant pockets of voters outside of the Deep South that liked Wallace because of issues like forced busing, cultural liberalism, and the left's virulent opposition to the Vietnam War and how it got bluntly reflected onto the American military (Lind, 2016). There is an eerie connection from this platform to Trump, where 
important Rust Belt voters were clearly connecting to him and not to Hillary Clinton (Ryan, 2016, p. 12). While liberal analysts were quick to jump on the ugly racial and quasi-racial rhetoric that Trump did not seem to care about launching randomly, these important blocks of voters seemed more moved by appeals that hinted at their own economic isolation, the intellectual arrogance that deemed them 'deplorables,' and de facto eliminating them as a relevant segment of society to even be concerned with (Clinton did not really campaign in these areas which, after the fact, seemed to be a critical strategic mistake) (Nicholas and Lee, 2016, A1).

As was seen in Russia with the deft maneuvering of populist discontent, Putin was able from a strong right position to reframe his own image and narrative so as to be considered truly "for the people" against the far left elite that was accused of forgetting the fate of ordinary people. In Putin's case, the far left elite was largely the global community-America in particular and the scholarly intelligentsia in some of the large Russian universities. Trump (or at least members of Trump's team if not he himself) did much the same thing: deftly positioning himself as the populist outsider, immune to the derision of the left-wing elite, that bicoastal Ivy League snobbery network that proudly declared the huge swath of America in between the East and West coasts as 'flyover' territory only and the people living there as barely relevant citizens (Kauffman, 2016).

As with the previous Russian analysis, it does not matter whether these perceptions are factually proven or evidence-based. In the end, this is political narrative being driven for political agendas. In which case, all that truly matters is the effectiveness to shape the perceptional narrative of key voters. Putin does that better than the Western global community that is against him and Trump did it better than the Democratic National Committee and Hillary Clinton leading up to and including the 2016 presidential election. The inability of those oppositions to accept their own weaknesses and seek out opportunities to improve only means both Putin and Trump will continue to have the upper hand when it comes to the populist title (Van Dyk, 2017, A15). In both cases, the general elite opposition could not believe a majority of the popu- 
lation would "buy in" to what it considered to be cheap manipulative empty political rhetoric. The problem with this logic is that it was and is actually feeding the very criticism Putin and Trump level against their opposition: that the elites do not take ordinary people seriously and when something confuses the elite, they simply attack and disparage regular folk. Obviously, the liberal elite in either case do not believe they do that and claim that they do not strive to give that impression to others. But the elite in both cases were outplayed and out-politicked.

Now, heading into 2020, this inability of the left in America to reclaim what has always historically been its rightful citizen foundation is becoming even more stark. Trump in the first few years of his presidency did not exactly catch legislative fire when it comes to creating new populist innovation. There has been very little legislative innovation at all, in fact, when it comes to bettering the lives of ordinary everyday working-class people in America (Martin and Haberman, 2019). And yet, despite what should be massive dissatisfaction and frustration within the key electorate that delivered the presidency to Trump, his overall popularity ratings with this group seem molded to his continued populist rhetoric. Under such conditions, the issue is not the gullibility or ignorance of this electorate, but the continued stubborn condescension and arrogance of the elite left to not even attempt to win over a key group back to the Democratic Party. This is why most of the diatribes on the left have focused simply on "getting out the vote" for 2020 , i.e., they outnumber the so-called deplorables and 2016 was simply an issue of ambivalence (Bennett, 2019). Perhaps this will prove true. But it could just as easily prove misplaced political hubris that once more delivers an equally devastating shock to all those on the left side of the American political spectrum.

\section{POST-TRUTH POLITICS AND COMPETING MODERN POPULISMS}

Throughout all of this, it has become easy to complain about the emergence of right-wing populism or the commandeering and management of popular definitions of just who the elite are. Those complaints, however, seem to be emanating more from the liberal side, as these innovations in populism and their subsequent effects 
on contemporary politics decidedly disfavor the left and their more traditional conceptualizations of populism. The problem, however, is that populism has from its very beginning been a concept open to adaptive construction and interpreted widely by many diverse actors. So, it may be an empty or hollow accusation to declare that the rightwings of any country should not be able to work with populism. It has long been proven it is not an exclusively left-wing ideation. But in this article perhaps the most pertinent thing is to emphasize how the shift from left to right is not really the crucial component in the negative rise of so-called right-wing populist movements. Rather, it is the fact that this shift has almost perfectly coincided with the rise of post-truth politics. Indeed, it can be argued the two are eerily effective at bringing out their own worst sides and they make this new era of competing modern populisms quite potentially disruptive.

While post-truth politics has currently become rather ubiquitous across the globe, the actual emergence of it as a concept tends to surprise people. The Oxford Dictionaries may have defined it as a "word of the year" in 2016, coming on the 1-2 liberal gut punch of first Brexit and then the election of Donald Trump as president of the United States, the term itself was formally invented as far back as 1992. Back then a Serbian-American playwright by the name of Tesich was interested in determining the true long-term behavioral and attitudinal consequences on the American generation that emerged from and grew up after the trauma of the Nixon Watergate scandal (Higgins, 2016, p. 9). His ultimate conclusions/reflections (this was not a formal academic study but something more esoteric and philosophical) were quite intriguing.

American citizens, post-Watergate, ultimately decided they no longer wanted bad or depressing news, even if that news was the truth or necessary to be known for political or national security or health reasons. Since the pursuit of such truth seemed to often coincide with revelations of bad news or bitter disappointment, Tesich surmised that the American people would actually prefer to be lied to. This seemingly cynical position, however, came with a very special and specific caveat: this preferred lying should happen in alignment with the personal preconceived interests, notions, and preferences of the people. In other 
words, the promotion of deception was like a philosophical and societal Xanax: America, as a free society, and Americans as a free people, have freely decided to live in a post-truth world.

To be fair, it is doubtful anyone could imagine this randomly coined term would acquire second life in the 21 st century. Originally inspired as an encapsulation summing up the consequences of a politically corrupt past on Generation X, it now seems to have caught fire across multiple American generations living in a digital millennial age and covering all things politically right now. In 2006, Stephen Colbert, a popular late-night comedian, coined the term 'truthiness,' which was meant to explain the penchant during the Bush administration's Global War on Terror to elaborate things "mostly factual" or "somewhat truthful" but with a healthy dose of political agenda-making and partisan bias. It was considered so perfectly apropos to describe the current political environment that the Merriam-Webster Dictionaries (in a forerunner of what Oxford would do a decade later) named 'truthiness' its word of the year (Staff, 2006).

So that no one would think all of this talk about the relevance of quasi-truth and its political significance evaded the realm of formal scholarship, in early 2016 a Nobel Prize-winning psychologist pushed forward the concept of 'cognitive ease.' This tied directly into the discussions of playwrights and comedians, but with more gravitas, as cognitive ease described the overwhelming tendency of humans as a species to avoid facts that would be challenging to their own preconceived notions. In short, hard science proved that the human brain was wired to reject attempts that would make it think uncomfortably or challenge previously held facts (Davis and Hicks, 2016, pp. 293-296).

To wrap up the evolution of post-truth as a concept in global society, one should consider the words of Dmitry Kiselyov, the (in)famous Kremlin propagandist-Moscow journalist, who summarized this zeitgeist in 2018 by cautioning everyone, but most of all Americans, when it came to this amazing all-access information age. In response to the criticism by America about supposed Russian social media interference aimed at compromising the 2016 American presidential elections, he 
derided the very concept of 'neutral journalism' (Staff, 2011b). To Kiselyov, the age of neutral journalism, if it ever existed, was most certainly dead. This was based on the mistaken assumption by the global community that the instantaneous and massive access to information marking this digital age is characterized by objective information. Kiselyov intriguingly argued that the information people select from the World Wide Web tends to already be subjective, politically engaged, and thus motivationally biased (Lipman, 2014, pp. 184-187). This adds a distinctive hard edge to the earlier understanding of post-truth. Whereas originally it was hopeful self-delusion to avoid bitter real truth, it is now an actively promoted and intentionally designed digital machine engineered to help justify and rationalize people to remain ignorantly committed to their own created, predetermined truths.

Disturbingly, post-truth has been found influencing and impacting more than just society. It is not just a person-on-the-street consideration, intimating that the elites and intellectuals are not affected. A simple perusal finds work being done on the detrimental impact of post-truth on such varied disciplines as conservation, globalization, education, and intelligence, just to name a few (Gross, 2017, R2). The common danger running through all of this is stark: ultimately, a post-truth world is one that simply rejects the value of data, rejoices emotionality, dismisses expertise, and arrogantly waves off objective intellectualism as elitist propaganda. While it is obvious why these trends would be anathema to every academic discipline and intellectual profession, they are especially damning to the integrity of politics and the legitimacy of grassroots activism. The principles of evidentiary data, non-subjectivity, apolitical evidence, highly developed expertise, and rational intellectualism should be the core bedrock upon which politics and activism are not just built but upon which they have always staked their relevance, reputation, and ultimate societal impact.

\section{LIBERAL ELITE AND POST-TRUTH UNITY:}

\section{THE DESTRUCTION OF RUSSIA-U.S. POTENTIAL?}

It is one thing to claim that little-known scholars writing for littleread journals about little-propagated theories that undermine science 
in favor of arbitrary societal constructs have minimal impact and do not need to be a concern for most citizens. But press forward into this current highly technologized world, where the scholars and peer-reviewed journals are so easily bypassed with instantaneous communication across a legitimately global audience, and the ideal foundation for the explosion and propagation of 'populist posttruth' becomes concretized. Additionally, global society needs to be careful about making this phenomenon anthropomorphized. The chronological evolution of post-truth proves it was an issue long before the political significance of both Donald Trump and Vladimir Putin. Post-truth is not dependent upon them occupying the chief political office in their respective countries. They both may be deft and agile manipulators of the phenomenon for their own political ends, but the chronology of time and present evidence show that they very well may be a symptom of post-truth, not its cause.

Affirming what one believes is not the same as confirming what one thinks. It is easy to recognize the distinction between affirm and confirm. What tends to be missed, however, is the significance of difference between believe and think. Affirming belief is a largely subjective process, given to emotions and rarely analytical. Confirming a thought is a mostly objective process, with no emotions involved, and supported through analysis. Whether post-truth will find victory or defeat in global society, it will be decided upon this intellectual battlefield. Living in a post-truth world matters for both politics and populism because it creates a society, a populace, and a working environment detrimental to their real purposes and functions, not just as an intellectual abstraction, but as a legitimate and thriving society.

A post-truth populist world creates a world of not just "stupider politics", but perhaps even "stupider people" overall. Most disturbingly, this dumbing down would not necessarily be by choice but by de facto ambivalence. And such a world is not only more ignorant and misinformed. It is more dangerous as well. This might be where Trump and Putin differ the most on their respective utilization of populism for political gain. While Putin has over the course of his career created and enforced real initiatives that were meant to improve the position of the 
disenfranchised across society, Trump's popularity within his specific political base has not really waned despite falling short on just about every populist campaign promise. Neither, to the liberal elite, may ever be called a "true" populist, but Putin has legitimate populist legislative acts to point to while Trump for now has literally none.

Thus, moving forward with future elections and consequential global affairs, the stakes are indisputably high as the true impact of power populism intertwines with post-truth politics. It is not just about how accurate or unbiased a country's social media environment is or how fair and just its leaders are. It also influences far too heavily general Russian-American relations and all to the worse. The discussions and arguments contained within this article could very well be the determining factors as to why countries remain allies, become adversaries, enjoy peace, or engage in war. Most depressingly, they may also remain quite relevant as to why Americans and Russians in their respective corridors of power continue to eye one another skeptically and thereby miss real opportunities to establish more positive and cooperative dialogue.

\section{References}

Acemoglu, D., Yegorov, G. and Sonin K., 2013. A Political Theory of Populism. The Quarterly Journal of Economics, 128(2), 771-805.

Aron, L., 2017. The Kremlin Emboldened: Putinism After Crimea. Journal of Democracy 28(4), 76-79.

Bader, M., 2009. Understanding Party Politics in the Former Soviet Union: Authoritarianism, Volatility, and Incentive Structures. Demokratizatsiya. 17(2), 100-120.

Bennett, G., 2019. Gillum Seeks to Register 1 Million New Florida Voters to Beat Trump. TCA Regional News, 21 Mar.

Berlanga, J., 2010. The Liberal Roots of Populism: A Critique of Laclau. CR: the New Centennial Review, 10(2), 151-182, 289.

Casula, P., 2013. Sovereign Democracy, Populism, and Depoliticization in Russia: Power and Discourse During Putin's First Presidency. Problems of PostCommunism, 60(3), 3-15.

DaVanzo, J. and Grammich, C., 2001. Dire Demographics Population Trends in Russia. Santa Monica: RAND Corporation. 
Davis, W.E. and Hicks, J.A., 2016. Judgments of Meaning in Life, Religious Beliefs, and the Experience of Cognitive (Dis)Fluency. Journal of Personality, 84(3), 291-305.

Ding, I. and Hlavac, M., 2017. 'Right' Choice: Restorative Nationalism and Right-Wing Populism in Central and Eastern Europe. Chinese Political Science Review, 2(3), 427-444.

Freebury, D. R., 2011. On Dissidents and Madness: From the Soviet Union of Leonid Brezhnev to the 'Soviet Union' of Vladimir Putin. Psychiatric Services, 62(8), 979-979.

Gross, M., 2017. The Dangers of a Post-Truth World. Current Biology, 27(1), R1-R4.

Gurganus, J., 2017. Putin's Populism Trap. Carnegie Endowment for International Peace. Nov 21.

Handelman, S., 1999. Russia's Rule by Racketeers. Wall Street Journal, 20 September, A28.

Higgins, K., 2016. Post-Truth: a Guide for the Perplexed. Nature, 540(7631), 9-9.

Hodge, N., 2019. The End of Liberalism? At the G20, Putin Sides with the Populists. CNN News. 28 June.

Huber, R.A. and Schimpf, C.H., 2017. On the Distinct Effects of Left-Wing and Right-Wing Populism on Democratic Quality. Politics and Governance. 5(4), 146-165.

Kauffman, G., 2016. 'Les Deplorables': Why Some Trump Supporters Have Embraced the Label. The Christian Science Monitor, 15 September.

Lassila, J., 2016. Aleksei Naval'nyi and Populist Re-Ordering of Putin's Stability. Europe-Asia Studies, 68(1), 118-137.

Leonov, Yu. S., 2013. On the Public Discussion of the Strategy of State National (Ethnic) Policy of the Russian Federation. Sovremennye Issledovaniya Socialnyh Problem, 1.

Lind, M., 2016. Donald Trump, the Perfect Populist. Politico.com. 9 March.

Lipman, M., 2014. Russias' Nongovernmental Media under Assault. Demokratizatsiya, 22(2), 179-190.

Martin, J. and Haberman, M., 2019. Trump Relies on Populist Language, But He Mostly Relies on Corporate Interests. New York Times. 23 July.

Mead, W., 2017. The Jacksonian Revolt: American Populism and the Liberal Order. Foreign Affairs, 96(2), 2-7. 
Mersol, J., 2017. When Russian Values Go Abroad: The Clash Between Populism and Foreign Policy. The SAIS Review of International Affairs, 37(1), 95-100.

Nicholas, P. and Lee, C., 2016. Clinton Makes Her Pitch-Nominee to Take on Trump in Rust Belt. Wall Street Journal. 29 July, A.

Nicholson, S.P., 2011. Dominating Cues and the Limits of Elite Influence. The Journal of Politics, 73(4), 1165-1177

Oliver, E.J., Rahn, W.M. and Bartels L.M., 2016. Rise of the Trumpenvolk: Populism in the 2016 Election. The ANNALS of the American Academy of Political and Social Science, 667(1), 189-206.

Plattner, M., 2010. Populism, Pluralism, and Liberal Democracy. Journal of Democracy, 21(1), 81-92.

Rose, G., 2016. The Power of Populism. Foreign Affairs, 95(6), 1.

Ryan, M., 2016. How Donald Trump Won the Rust Belt. Billboard, 128(30), 12. Shinar, C., 2015. The Russian Oligarchs, from Yeltsin to Putin. European Review, 23(4), 583-596.

Smith, D.G., 1955. Lenin's 'Imperialism': A Study in the Unity of Theory and Practice. The Journal of Politics, 17(4), 546-569.

Staff, 2002. Russians Can't Get Enough of 'A Man Like Putin.' National Post, 27 Aug: A1 / FRONT.

Staff, 2006. What's in a Word? Dictionary.com Asks Users to Cast Vote for the 2006 Word of the Year; 'Truthiness' Voted as Top 2006 Word; The Most Searched-for Word Was 'Love.' PR Newswire. n/a.

Staff, 2011a. Corridors of Power; Putin Criticizes 'Democracy' for Showing Gaddafi Killing to the World. Interfax: Russia \& CIS Military Information Weekly, 16 Dec.

Staff, 2011b. Television and Presidential Power in Putin's Russia. Vol. 00070.

Staff, 2016. Pepe and the Stormtroopers; Trump and the Alt-Right. The Economist, 420(9007), 41-44.

Treisman, D., 2011. Presidential Popularity in a Hybrid Regime: Russia under Yeltsin and Putin. American Journal of Political Science, 55(3), 590-609.

Van Dyk, T., 2017. The Democrats' Biggest Problem Is Cultural. Wall Street Journal, 28 July, A.15.

Winberg, O., 2017. Insult Politics: Donald Trump, Right-Wing Populism, and Incendiary Language. European Journal of American Studies, 12(2).

Young, C., 2018. Dissent and Disarray in Putin's Russia. Reason, 50(6), 26-33. 